From argumentation to argument: Interaction in the conference hall

\title{
Pauline Webber
}

\section{OpenEdition}

\section{Journals}

\section{Electronic version}

URL: http://journals.openedition.org/asp/3256

DOI: 10.4000/asp.3256

ISSN: 2108-6354

\section{Publisher}

Groupe d'étude et de recherche en anglais de spécialité

\section{Printed version}

Date of publication: 1 December 1997

Number of pages: $439-450$

ISSN: 1246-8185

\section{Electronic reference}

Pauline Webber, « From argumentation to argument: Interaction in the conference hall », ASp [Online] 15-18 | 1997, Online since 26 November 2012, connection on 20 April 2019. URL : http:// journals.openedition.org/asp/3256 ; DOI : 10.4000/asp.3256

This text was automatically generated on 20 April 2019.

Tous droits réservés 


\title{
From argumentation to argument: Interaction in the conference hall
}

\author{
Pauline Webber
}

\section{Introduction}

1 Argument is a frequently occurring word form in English, listed in the second band out of five frequency bands in the COBUILD corpus. In English, however, it is used in two main senses, which are not always cognate with similar forms in other European languages (Italian, French). On the one hand, there is the sense of "making an argument", that is, using reason, evidence and claims to validate a hypothesis, and on the other, "having an argument" or having an interactive disagreement or dispute. In the latter case, "heated argument" is a frequent collocation, showing that in this sense it has connotations of conflict and aggression.

2 There is a wealth of literature on argumentation and conflict talk, but the venue of the conference has been little visited. A notable exception is a paper on Discussing discussions given by Ventola in Mexico City, 1996. She considers the papers and discussions as speech acts, in which the discussion may be seen as linked to the paper or as a separate activity set off by a framework.

In scientific presentations, both senses of "argument" are relevant to the proceedings, that is both logical reasoning, used predominantly, but not exclusively, in the pre-planned phase of the platform talk, and the language of dispute, which may come to the fore in the free exchange phase.

4 This study considers a corpus of attested samples of data collected from international scientific meetings. Its purpose is not to evaluate the soundness of the arguments, but to describe the language behaviour of participants in public discussions. 


\section{The platform presentation}

5 The main focus of this paper is the question and answer session, but as the questions refer to the presentation, which constitutes a sort of extended turn in which one speaker has uninterrupted access to the floor, it is necessary to describe briefly some discourse features of the presentation itself. The questions are in a way the second turn in the interaction, although, by comparison with everyday conversation, it is far more restrained by the rules of the game, in which only a few minutes can be devoted to the open discussion and participants are rarely allowed to ask more than one question. This means that each single exchange is terminated or truncated by time constraints and so outcomes may be deferred or left open or (less frequently) resolved, without any evident "winners" or "losers".

6 Argumentative logic forms the basis of scientific reasoning and of the persuasive rhetoric of scientific discourse, but it is combined with the presentation of facts to persuade the recipient. In the workshop sessions of conference presentations, speakers normally use recognisable argumentative discourse patterns to take the listeners through a stepwise series of statements to try to convince them of the truth of their hypotheses. The pattern may vary, but will often consist of three parts, corresponding to what has been referred to above as reason, evidence and claim, that is:

7 1. a. Rationale and aims,

8 b. Study design,

9 2. Details of the results includingstatistical data, figures and quantification of evidence,

10 3. Conclusions drawn from the results.

11 In the first and last sections the discourse tends to be more speculative, and so more rhetorical, as authors set forth the reasoning behind their research protocol and the attempted interpretation of the findings. As noted by Walton (1992) the order of proving is quite different from the order of finding and may be closer to what Aristotle called the demonstration. For Aristotle, in scientific inquiry, or demonstration, proof must proceed only from premises that are either axiomatic or can be established by methods of inference according to the standards of a particular branch of scientific knowledge.

The linguistic strategies used within this framework are thus in part those well established in rhetoric since the days of ancient Greece, using the evidence and counter evidence of critical reasoning. In part, however, since some of the strategies used are specific to scientific discourse, the principles applied are those laid down by scientists such as Galileo, in that the methods used must be seen to be repeatable and claims must be based on experimentation. The argumentation of scientific discourse leads to a claim. A fairly outspoken example of the claim statement is the following: "So in conclusion, I can tell you that the sensitivity is elevated and that $\mathrm{x}$ is a predictor...» The claim is at the centre of the scientific paper, but as it must be based on the results of experiments or observation of facts, in modern scientific language doing and thinking arebrought together (Halliday 1993).

Traces of this manner of reasoning are apparent in passages such as the following sample: "This (influence of ICA) was used as an argument that the appearance of ICA in first degree relatives can be used as a marker for progression to clinical diabetes". Here in the "that" clause it is a process which is used grammatically as the subject of the clause 
and in thematic position, implying a cause-effect relationship, hence logically as an argument in building up a hypothesis. This is characteristic of scientific prose, where processes and qualities or results have taken the place of persons. The person who observes the phenomenon does not appear in the clause structure.

Particularly in the results section, speakers use language which emphasises the objectivity of the data, using impersonal subjects, often with anticipatory it, as in the following: "it turns out, though, that" "it appears from our study that". In this section, the focus is on factual information and orientation is to results shown on the slides. The following is a brief sample of the many instances of this kind of discourse:

First of all, you can see that ICA $\mathrm{n}$ or $\mathrm{n}$ antibodies tested by ELISA are clearly elevate. In the next slide we can see that also the titres are different.

The message is that the evidence is "clear" and obvious to the beholder, without any need of explanation or persuasion on the part of the speaker. However, as noted by Tarantino (1995) the interpretation is built on the speaker's and audience's mutual critical evaluation of the facts presented. The background to the interpretation is a common pool of accepted scientific knowledge. The facts presented may also be carefully selected to support the hypothesis.

Some of the strategies used in conference discourse are commonly found in other kinds of public speaking. Among these is the tendency to take for granted some piece of information as accepted and common knowledge, particularly in the introduction, but also in the concluding interpretative section:

"as there is a strong association between $\mathrm{x}$ and $\mathrm{y}$, as we all know.."

"trials are being carried out, as you all know.."

"Well, yOU know better than I do that"

These represent a bid for alignment, and from this base of presumed common knowledge, the speaker can move on to put forward a new hypothesis. Any new ideas need to be introduced with caution and more persuasive strategies are used in these parts of the text. As shown by Adams Smith (1984) in written articles, the more attitudinally marked sections of oral presentations are the introduction (rationale and study design) and conclusion.

Towards the end of the paper, in the interpretation of findings, in fact, we may find persons (the researchers themselves) in thematic position, so that evaluative attitudes are highlighted:

"So one of the questions was 'Do we measure IC antibodies the same way in all different laboratories throughout the world?', (because this assay became rapidly used by many investigators). To our surprise, the answer was no"

"to my amazement, we saw less infection"

20 In these last examples, the speaker's attitude becomes explicit, whereas in the more objective language of the results section the speaker strives to give the impression that the facts speak for themselves. Of course, in reality the speaker's choice of language is vital in setting forth the critical argument underlying the claim, in order to convince other members of the scientific community. When the findings are made public, scientists who have mastered the characteristic features of scientific English will be more able to make their claims widely known. Ultimately, therefore, discourse performance becomes a crucial part of scientific activity and publication. 


\section{Question-answer session}

21 The workshop talk is followed by a free exchange phase when the chair invites questions from the floor. Here there is a change in the kind of discourse. Although scientific reasoning is still at the base of the interaction, in two-way communication other factors come into play. These are dictated by social and politeness conventions of the discourse community, by the desire to win recognition for the speaker's ideas and work in the agonistic milieu of the academic community, and by the way the interaction is built up jointly in the question-answer session.

22 Furthermore, in face-to-face interaction there is an element of risk, as it takes place in public, and arguers are open to critical challenge and must justify their points of view, or rather, the positions they are openly committed to. We never know if the animator is also the principal or sole author of the talk (in Goffman's terms) or represents a school. Schools often have conflicting opinions. Where animator and author coincide, the speaker may introduce unplanned elements and his or her personality may show through the text. Unlike casual conversation, these exchanges are institutionalised in the sense that speakers may intervene from the floor only on the invitation of the moderator, who acts as intermediary between speaker and audience, and in the sense that certain standards of behaviour are expected. The questions are also consequential to the paper which has just been presented, of which the summary in the programme has already provided listeners with an outline of the content. Some of the questions may therefore be predictable, but this is not always the case. So talks are planned to a certain extent, whereas conversation is entirely free.

This phase therefore shares only some of the features typical of discussions in casual conversation. Officially, the purpose is to find the truth rather than to win over the other party as in everyday disputes. Attempts to defeat or even humiliate the other participants would not be considered appropriate in polite public discussion. In reality, however, there may be motivations of ambition and competition underlying the surface politeness (Myers 1989).

24 Among the many types of question found in the data, some are simply requests for further information or clarification. These may often come from the esoteric audience. Secondly, there are questions which are essentially suggestions to the researchers for ways of solving problems or doing further research. A third type consists of potentially threatening questions which attack or criticise the study presented. These are quite frequent and come mainly from members of the esoteric audience, in this case, people working in the same field, who have often done similar research and may be able to pick holes in the speaker's study. Finally, there is a type of question which is not really a question at all, but rather an opportunity to make a comment on some aspect of the topic. The questions from the inner circle of experts in the same speciality are those which speakers fear most, as participants have pointed out to me. Today research is increasingly narrower and deeper, so that we find groups constituting a speciality within the speciality. It is because of this potential threat of criticism from opponents that towards the end of a paper it is not unusual to find comments which serve to forestall possible criticism, such as: "There are those that are unimpressed with data, but..." classification but simply a system of convenient labels for the purposes of this study. In 
fact, it is not at all easy to classify these different questions types. In some cases, specialist informants present at the proceedings were consulted, but it must be admitted that even insiders can only give their own interpretation, although they will undoubtedly understand better than the linguistic researcherwhat is really going on. The nature of language is such that emic interpretation are also subjective and may be "wrong". It is characteristic of the indeterminacy and flexibility of natural language that utterances may be taken in different ways. If this were not so, misunderstandings between speakers would not occur, but it would also not be possible to express vaguely conceived ideas and uncertain hypotheses which often make up scientificspeculation.

Many researchers see critical discussion as occurring through the exchange of speech sets (Van Eemeren 1984; Jacobs 1986; Jackson 1992). Questions are important in the exchange, because they force respondents to commit to an answer and so, without directly challenging them, pin them down to expressing an idea. The utterances cannot always be taken at face-value but must sometimes be taken at a deeper level. A seemingly innocent request for information may in fact be a veiled criticism.

The fact that participants are aware of the expected compliance with rules is illustrated by remarks on felicity conditions of authority, such as the following;

Q. "Am I allowed to elaborate on that answer?"

Antaki (1994) claims that speech act theory is not sufficient to identify what social action is done in an argument, whereas conversation analysis treatment is more revealing of participants' own understanding of what is going on. The exchange may not turn into an argument unless the first speaker's utterance is picked up by the second speaker so that a dispute is sparked off. Thus, even a pointed accusation may not always lead to a dispute.

Antaki's analysis, however, applies to disputes which become overt, whereas there are many cases where a counter-argument may be implied but no open quarrel takes place. In conference discussions, open conflict is the exception rather than the rule, so this study does not consider only open conflict, but any contribution to the argument, in a positive or negative sense.

Let us start from a sample exchange:

Chair "The paper is now open for discussion."

Q. "Nice study. The question is, of course, how long does this last?"

A. "I don't really know."

Q. "My surprise is, anaerobic exercise increased by so much. There was a decrease in total fat in your control group. How do you explain that?"

A. "I think body fat is not a good predictor, whereas adipose tissue is."

And later, in the exchange with the same speaker:

Q. "Can I ask you - did you also measure free fatty acids, because..."

R. "No, we didn't."

In the first exchange, the brief compliment is followed by a remark which points out a shortcoming in the results, that is, they may be short-lived. From the tone of voice, it appeared to be a case of mild objection. The speaker made no attempt to offer any further information on this. The speaker defended herself more determinedly in her second reply to the same questioner. In the third exchange, however, she gave a straight negative. Respondents, in fact, do not always pick up the challenge.

When the opening words of appreciation are followed in this way by some objection, the utterance is very reminiscent of the "Yes, but ..." strategy used so often in everyday conversation. 


\section{Praise}

Expressions of appreciation as in the above extracts are used very frequently as opening phrases leading to the questions, whether out of genuine admiration or for reasons of politeness. The following are some samples from the corpus:

"I was very stimulated by your talk"

"A lovely paper!"

"An absolutely fascinating paper!"

"Congratulations on the work you have done"

\section{Requests for information}

Q. A series of beautiful work done by your group. Uhm, have you tested diabetic sera, and if so... er ... as opposed to normal controls, is there any association?

A. Well, $\mathrm{x}$ is expressed in tissues in the liver and kidneys, and we have tested only a limited number of patients ... that might be possible but these still have to be confirmed.

Q. Do you think that these reflect...?

A. I think it would be very dangerous to maintain there is no difference-we have not found a difference, that's all. I think that further studies are indicated.

Q. I didn't quite catch

A. I can explain that What was your second question, please?

$\mathrm{Q}$. The question was whether the improvement was due to $\mathrm{x}$ or $\mathrm{y}$

A. I didn't mention this, because this study was not randomised.

$\mathrm{Q}$. As you pointed out, $\mathrm{x}$ is important as a regulatory step. In your experience, is it possible to regulate.. ? It might be important because...

A. You would have to obtain liver tissue to measure the activity. As far as I know, this has never been done.

Q. I'd like to make two comments...

A. As far as the first question is concerned...I take your point

Q. Could you please comment...

A. We don't undertake overall screening of cirrhotics...

The following is an example of a follow-up:

Q. John, correct me if I'm wrong, but... Have you any indications for this?

A. We believe the insulin used now still has many impurities.

Q. So this is true for IV?

A. It's probably true, yes.

\section{Suggestions}

Very often questioners compare the speaker's work or results with their own:

"Thank you very much. Very challenging data there. We tried to do something similar... but our preparation is very short-acting. Just a point on the administration, I was just thinking, the dose wasn't very high. I was wondering, couldn't you..."

The following intervention might have been a criticism, but specialist informants we interrogated among the participants considered it was more likely to be meant simply as a suggestion:

"I'm going to make a comment which is a bit speculative... Looking at the strategy,

I wondered if it would not be wiser to separate the group... I wonder if it could not 
be a marker of $\mathrm{x}$ or something like that. Do you think there is any sense in associating the 2 clusters of genes?"

In cases like this, only the participants know how to interpret the value of the utterance, according to schemata based on experience in similar situations, to distinguish among permissible interpretative options.

\section{Criticism}

The following are more evidently critical and attempt to undermine the paper in some way:

Q. I find it difficult to imagine that $\mathrm{x}$ could produce $\mathrm{y}$. I wonder if there may not be some factor which does not function in the presence of $\mathrm{x}$ and if these investigators have attempted to discover if...

A. First of all, we tried to determine if the same level is preserved, but the data are not available yet. Secondly we tried to determine x... There must be other factors...IGF-like factors

8 Here the questioner criticises the premises of the speaker's argument. The respondent offers the excuse that they have not yet finished the study, but intend to carry out further investigations, and seems to concur in part with the questioner's observation.

The following are further samples of questions which seem more evidently critical:

Q. I'm not sure I could accept your upper values. Are you sure this will prevent microangiopathy?

Q. I am a little bit concerned about the right period which is the most critical period. How do you cope with this problem? Your point is well put, but I think you have misunderstood the $\mathrm{x}$. It's not a matter of this causing hyperglycaemia...

Q. I'd just like to express a little caution about comparing different drugs on a percentage wise basis.

Q. Your results are optimistic. I must confess I am somewhat sceptical about your interpretations.

There are several kinds of response to the question or comment. These include: avoidance and evasion, reformulation, excuses and justifications, denial, attack, submission. In some cases, respondents defend their position:

"There must be a misunderstanding: the rise is always between 2 and 4 a.m."

In other instances, respondents offer no information:

"I have no information on long-term use of these injections."

There are also cases of submission, as in this case, where the speaker is accused of bias:

Q. Actually, we showed there was no long-lasting effect. Secondly, I think we have to be very, very careful in talking about remission. Just a warning- your results are interesting, but they could be due to the fact that you were more aware of x...

A. I agree with you, especially with the second part.

Some speakers defend their position more strongly:

A. I think that before jumping to conclusions, we have to find out.. I think we have to wait for the results of the trials, Even though I admit there are no clear-cut scientific grounds for the treatment, it would be unethical to withhold it.

Again, we find many instances of comparison with the questioner's work:

Q. I think you cannot judge if you don't test for ICA first. We have now tested over 1000 babies, so I think from your study you can't really say that x precedes y ... or with that of others:

Q. I think it is not appropriate to compare your programme to what was presented before by K. Could I persuade you that your educational programme had absolutely 
no effect?

A. I agree that there is no comparison with the K. group. The other point, I would not be so pessimistic. I simply told the audience what we achieved. I would say if we had had new tools the results would have been even better. As regards the rest, I agree it was a failure.

At times other participants join in the debate, which may last longer than the usual two turn interaction:

Q1. Giorgio, you know how much I like your work, but I just can't understand: you take 23 patients and you say you found but this was predictable because they were older. First of all, what do you mean by "express"?

A. First, thanks for saying you like my work. I would like to point out that the correlation we have described was definitely significant.

Q2. I think Giorgio is right. I think what he is saying is ...

(The names in the above exchange are fictitious).

Here again, we have a general compliment, followed by the accusation that the speaker has made a hasty generalisation because of the small sample, then by a request for more precise definition of a term used by the speaker (a common move in the rhetoric of challenging arguments). The speaker is given support by another member of the audience who belongs to the same group. The speakers involved were Italian (one living in the UK), but the whole exchange took place in Stockholm and in English. In this case, when we asked why this dispute arose, informants were of the opinion that speaker A1 was a researcher of lively intelligence who regularly engaged in arguments through love of polemics.

In another exchange, the accusations became unusually pointed, and again a third party comes to the rescue of the speaker:

Q1. We have done some experiments in Holland and found the drug has effect of $x$

A1. I am not familiar with that effect

A1. I am not familiar with that effect

(the first participant continued to insist on his point of view)

A2. "But that's impossible!"

At this point, the platform speaker A2 was shouted down by other speakers from the floor, one of whom found a satisfactory resolution to the conflict by observing:

Q2. This effect has been shown in vitro, but not in vivo...Does this answer your question?

This represents a rare occurrence of conflict coming out into the open and becoming closer to what might be considered more characteristic of quarrels in casual conversation, as the turn-taking procedure momentarily breaks down. The dispute is sparked off by speaker A2, whose direct accusation goes beyond the bounds of what is normally considered polite in the context. That this is «off key» is evident when we compare the utterance with the language of the rest of the data above, including A1, an older (perhaps more experienced) speaker on the platform panel, whose remark «I am not familiar with that» seems a plea of ignorance of the facts on the part of the speaker, but may in fact implicitly cast doubt on the truth of the questioner's proposition, especially if the speaker is a recognised expert. Here power relations are also important in interpreting the intervention.

Many of the interventions recorded in the corpus show extreme caution and hedging in the choice of language. This is expressed through the use of devices such as adverbs: "I'd just like to express a little caution", "I just wanted to know", "Actually, we showed"; 
modals: "I'm not sure I could accept your upper values"; vague quantifiers: "something around 40\%", "a year or so ago", "These data are somewhat scanty in the literature"; verb choice: "I wonder if...", "Are you suggesting that...?". Many questioners give an impression of caution by using self-reference, as in all the samples just cited, except the last. The last sample, however, uses the second person, and so tries to tie the speaker down, which might seem more threatening ("are you suggesting...?").

The choice of language is closer to casual conversation in the question-answer session in the use of such elements as non-clausal constructions, informal expressions and fixed expressions, such as the following:

"Just to tackle your question specifically", "This is just a straw in the wind", "the team have gone about it in the most cautious and professional way", "you're up against a rival there".

As may be seen from the examples cited, the discussion also includes frequent references to other experiences, comparisons with other research positions and claims published elsewhere, found in the examples cited above. These intertextual elements belong to the vast network of the research front which the discourse community is involved in.

\section{Conclusion}

51 Argument is a topic which concerns many different disciplines, such as rhetoric, sociology, or psychology, but it is particularly interesting for linguists because it is an activity which is realised through language. Argument is both a linguistic construal of experience in one sense and a dispute or debate built up through language by two or more interlocutors in the other. Van Ermeeren (1986) defines argumentation as any attempt to justify or refute an opinion by verbal means, directed towards the approbation of an audience. He claims that there is always potential dispute underlying any public declaration of claims, whether it is externalised or not. We may consider therefore that this implicit tension can become explicit in the free exchange phase. Disagreement-relevance thus underlies both uses of the term argument: making an argument and having an argument. Superficially, it is the desire to maintain or establish a state of alignment which regulates disagreement-management. In reality, there may be other forces at work, such as the desire to defeat opponents and gain support for one's own ideas. In a period of limited resources, competition can be fierce, because winning recognition can mean obtaining not only prestige for participants and their partners but also more funds for research. The sources of dispute may be hidden: possibly a feeling of grudge on the part of a scientist whose paper has not been accepted for the conference or some other interest which may stem from scientific convictions, personal preferences, or even commercial interests.

Lakoff and Johnson (1980) go further, in that they see our whole world view as permeated with images of conflict, and so even rational argument is thought of in terms of combat, expressed in the many war metaphors people use. People thus "plan their strategy", "marshal their forces" and "attack" opposing points of view, after considering what may be the weaknesses in the antagonist's position. They "defend" their own position and during the exchange there may be moves of retreat, counterattack, stalemate or surrender. The authors maintain that in a conflict of opinion, there is something to be won or lost, because one party wants the other to give up an opinion. 
53 As the stakes in the question-answer sessions at scientific conferences are high speakers are always ready to face opposition, and so we may consider that there is in fact a link between the two senses of the word "argument". The argumentation of the more rational content of the interaction in which speakers go through the reasoning behind their claims serves to convince those who are of a different opinion and so overcome potential opposition to the speaker's ideas and is thus linked to the underlying or open argument between opponents which can emerge during the discussion.

\section{BIBLIOGRAPHY}

Adams Smith, D. 1984. “Medical discourse: aspects of author's comment”. ESP Journal 3.

Antaki, C. 1994. Explaining and Arguing. London: Sage.

Aristotle. 1955. On Sophistical Refutations, trans. E.S. Forster, Loeb Classical Library, Cambridge, MA: Harvard University Press.

Fogelin, R.J. \& W. Sinnott-Armstrong. 1991. Understanding Arguments, 4th ed. Orlando: Harcourt Brace.

Goffman, E. 1978. “Footing”. Semiotica 25, 1-29.

Grimshaw, A.D. 1990. Conflict Talk. Cambridge: Cambridge University Press.

Grootendorst, R., S. Jackson \& S. Jacobs. 1997. “Argumentation”. In Van Dijk T. A. (ed.), Discourse as Structure and Process. London: Sage.

Halliday, M.A.K. and J.R. Martin. 1993. Writing Science: Literacy and Discursive Power. London: The Falmer Press.

Jackson, S. 1992. "Virtual Standpoints" and the pragmatics of conversational argument. In van Eemeren et alii (eds.), Argumentation Illuminated. London: Vale Press.

Jacobs, S. 1986. “The management of disagreement in conversation”. Invan Eemeren (ed), Argumentation-perspectives and approaches. Dordrecht: Foris.

Lakoff G. \& M. Johnson. 1980. Metaphors we Live By. Chicago: University of Chicago Press.

Myers, G. 1989. “The pragmatics of politeness in scientific texts”. Applied Linguistics 4, 1-35.

Tarantino, M. 1995. "ESP in an interdisciplinary perspective: the source and constituents of scientific communication". ALSED-ESP Newsletter 18, 1.

Van Eemeren, F.H. 1984. Speech Acts in Argumentative Discussions. Dordrecht: Foris.

Van Eemeren, F.H. 1986. "The normative reconstruction of argumentative discourse". In Discourse Analysis and Public Life. Papers of the Groningen Conference on medical and political discourse. Dordrecht: Foris.

Walton D. 1992. The Place of Emotion in Argument. University Park, PA: Pennsylvania State University Press. 


\section{ABSTRACTS}

This study is based on a corpus of taped recordings of scientific conference proceedings on similar topics held in English in various parts of the world. The purpose of the project was to analyse the linguistic realisations of persuasive rhetoric, solidarity and dispute, especially in the question and answer sessions following the talks. In cases which were not clear to the language specialist, subject specialist informants were consulted to interpret data. The analysis shows how the language of these events, while generally constrained by expected conventions of politeness and a sense of belonging to the same scientific community, can at times degenerate from argumentation to argument, when underlying disputes are brought out into the open. Disputes range from cautious disagreement to outright conflict in a few cases. There are many samples of indirect language and veiled criticism as well as instances of overt controversy.

Chaque communauté de discours a son propre code de comportement communicatif. C'est seulement en étudiant attentivement comment fonctionne une langue dans le contexte de l'acte de parole que nous comprenons les nuances de la langue. Nous avons étudié un corpus d'enregistrements de conférences scientifiques sur des sujets semblables ayant eu lieu en anglais dans plusieurs parties du monde. Notre but était d'analyser les réalisations linguistiques de la rhétorique de persuasion, d'union et de division, surtout dans les séances des questions/réponses succédant aux discussions. Nous voyons que le langage, tout en respectant les normes de politesse et de la communauté scientifique, peut dégénérer d'argumentation en dispute quand des conflits sous-jacents préexistants sont révélés.

\section{INDEX}

Mots-clés: argument, congrès scientifique, dispute, rhétorique

Keywords: argument, argumentation, rhetoric, scientific conference

\section{AUTHOR}

\section{PAULINE WEBBER}

